\title{
PENGARUH SUKU BUNGA, NILAI TUKAR RUPIAH, INFLASI DAN HARGA MINYAK DUNIA TERHADAP IHSG DI BEI
}

\author{
Reagan Wijaya Sumitra \\ Program Studi Magister Manajemen Universitas Tarumanagara \\ reaganwijaya1987@gmail.com \\ Carunia Mulya Firdausy \\ Program Studi Magister Manajemen Universitas Tarumanagara
}

\begin{abstract}
This research is to analyze the influence of macroeconomic towards composite share price index in Indonesia. This research is an explanatory research with quantitative paradigm. This research is using secondary data and the sample determined by full sampling technique based on time series date that has been accessed on official website of Bank Indonesia and finance yahoo year 2013 to 2017 which is consist of 60 samples. This research used multiple linier regression analysis. Based on classic assumption test, the datas in this research has been comply the assumption. Based on the multiple linier regression test, exchange rates and crude oil price has positive effect, whereas the inflation and interest rates has negative effect on composite share price index. Based on $\mathrm{R}^{2}$ test, 73,3\% of composite share price index influenced by interest rates, exchange rates, inflation and crude oil price. Based on F test, macro economic factors simultantly influence composite share price index. Based on $t$ test, interest rates and exchange rates has a significant effect on composite share price index, whereas the inflation and crude oil price did not have significant effect on composite share price index.
\end{abstract}

Keywords : Composite Share Price Index, interest rates, exchange rates, inflation, crude oil

\section{PENDAHULUAN}

Investasi merupakan komitmen sejumlah dana untuk tujuan memperoleh keuntungan di masa depan. Semakin menjanjikannya dunia pasar modal membuat begitu banyak orang mulai berinvestasi di dunia pasar modal. Tujuan investor menanamkan dananya di pasar modal adalah untuk mendapatkan keuntungan (return) tertentu dengan risiko minimal, atau keuntungan setinggi-tingginya dengan risiko seminimal mungkin.

Pasar modal merupakan salah satu instrumen ekonomi yang dewasa ini mengalami perkembangan sangat pesat. Pasar modal memiliki peran penting bagi perekonomian suatu negara karena pasar modal menjalankan dua fungsi sekaligus yaitu fungsi ekonomi dan fungsi keuangan. Pasar modal dikatakan memiliki fungsi ekonomi karena pasar menyediakan fasilitas atau wahana yang mempertemukan dua kepentingan, yaitu pihak yang memiliki kelebihan dana (investor) dan pihak yang memerlukan dana (issuer). Pasar modal dikatakan memiliki fungsi keuangan, karena memberikan kemungkinan dan kesempatan memperoleh imbal hasil bagi pemilik dana, sesuai dengan karakteristik investasi yang dipilih (Darmadji dan Fakhruddin, 2006: 2).

Salah satu indeks yang diperhatikan investor ketika berinvestasi di Bursa Efek Indonesia adalah Indeks Harga Saham Gabungan. Indeks ini mencakup pergerakan harga seluruh saham biasa dan saham preferen yang tercatat di BEI. Oleh karena itu melalui pergerakan indeks harga saham gabungan, seorang investor dapat melihat kondisi pasar apakah sedang bergairah atau lesu. Indeks harga saham gabungan yang turun menunjukkan 
kondisi pasar yang sedang lesu dan jika indeks harga saham gabungan mengalami kenaikan menunjukkan kondisi pasar yang sedang bergairah.

Perubahan pada iklim makro sangat mempengaruhi investor dalam mengambil keputusan investasi. Perubahan nilai indeks saham di BEI dipengaruhi oleh beberapa faktor makro ekonomi dalam negeri, antara lain inflasi, nilai tukar rupiah terhadap dollar dan suku bunga SBI (Sertifikat Bank Indonesia). Faktor makro ekonomi luar negeri seperti harga minyak mentah dunia juga ikut mempengaruhi nilai indeks saham di BEI.

Perubahan makroekonomi di Negara Indonesia tentu akan mempengaruhi perekonomian nasional serta seluruh industri. Contohnya inflasi yang tinggi dan melemahnya rupiah akan membuat banyak industri mengalami goncangan, produksi yang menurun akibat harga - harga bahan baku yang terus naik yang mengakibatkan menurunnya tingkat laba. Dengan menurunnya tingkat laba tentu akan memberikan dampak pada turunnya harga saham di industri tersebut karena dividen yang akan diterima oleh para pemegang saham akan menurun sehingga banyak investor yang akan menarik investasi mereka. Naiknya suku bunga akan membuat para investor lebih tertarik untuk berinvestasi dalam bentuk tabungan di bank daripada investasi di pasar modal. Menurunnya harga saham pada industri akan berdampak juga pada turunnya nilai Indeks Harga Saham Gabungan (IHSG) pada Bursa Efek Indonesia (BEI).

\section{TINJAUAN PUSTAKA}

\subsection{Suku Bunga BI}

Suku bunga acuan Bank Indonesia atau BI Rate adalah suku bunga kebijakan yang mencerminkan sikap atau stance kebijakan moneter yang ditetapkan oleh bank Indonesia dan diumumkan kepada public (Bisnis.com, 2015). BI pada umumnya akan menaikkan BI Rate apabila inflasi ke depan diperkirakan melampaui sasaran yang telah ditetapkan. Sebaliknya, BI akan menurunkan BI Rate apabila inflasi ke depan diperkirakan berada di bawah sasaran yang telah ditetapkan. BI Rate adalah suku bunga instrumen Bank Indonesia yang ditetapkan pada Rapat dewan gubernur triwulan untuk berlaku selama triwulan berjalan (satu triwulan). BI rate mencerminkan kondisi perekonomian di Indonesia, ketika terjadi perubahan kondisi perekonomian di Indonesia, BI meresponnya dengan menaikkan/menurunkan bi rate.

Bank Indonesia melakukan penguatan kerangka operasi moneter dengan memperkenalkan suku bunga acuan atau suku bunga kebijakan baru yaitu BI 7-Day Repo Rate, yang akan berlaku efektif sejak 19 Agustus 2016. Selain BI Rate yang digunakan saat ini, perkenalan suku bunga kebijakan yang baru ini tidak mengubah stance kebijakan moneter yang sedang diterapkan.

\subsection{Nilai Tukar Rupiah (Kurs)}

Nilai tukar atau kurs adalah perbandingan antara harga mata uang suatu negara dengan mata uang negara lain. Misal kurs rupiah terhadap dollar Amerika menunjukkan berapa rupiah yang diperlukan untuk ditukarkan dengan satu dollar Amerika (Musdholifah \& Tony, 2007).

Dalam sistem pertukaran dinyatakan oleh yang pernyataan besaran jumlah unit yaitu "mata uang" (atau "harga mata uang" atau "sarian mata uang") yang dapat dibeli dari 1 penggalan "unit mata uang" (disebut pula sebagai "dasar mata uang"). sebagai contoh, dalam penggalan disebutkan bahwa kurs EUR-USD adalah 1,4320 (1,4320 USD per EUR) yang berarti bahwa penggalan mata uang adalah dalam USD dengan penggunaan penggalan nilai dasar tukar mata uang adalah EUR

Terdapat beberapa jenis kurs atau nilai tukar, yaitu :

1. Kurs Beli (Bid Price) adalah besar satuan mata uang negara lain yang harus diserahkan untuk membeli tiap unit uang asing kepada Bank atau money changer 
2. Kurs Jual (selling price) adalah besaran satuan mata uang negara lain yang akan diterima dari bank atau money changer jika kita membeli mata uang asing.

3. Kurs Spot adalah nilai valuta asing yang digunakan untuk transaksi spot dipasar valuta asing.

4. Kurs Forward, adalah nilai tukar yang berlaku dan digunakan untuk transaksi forward dipasar valas.

5. Kurs Silang adalah nilai antara dua valas yang diperoleh dari nilai tukar masing-masing valuta terhadap valuta lain.

6. Kurs Opsi adalah kurs yang ditetapkan dimuka sesuai dengan pendapat Shapiro (1996:116) Yaitu, "Call option give the customer the right to purchase, but option give the right to sell the contracted currencies at the expected date"

\subsection{Inflasi}

Inflasi adalah suatu proses meningkatnya harga-harga barang secara umum dan terusmenerus berkaitan dengan mekanisme pasar yang dapat disebabkan oleh berbagai faktor, seperti peningkatan konsumsi masyarakat, berlebihnya likuiditas di pasar yang memicu konsumsi atau bahkan spekulasi, dan akibat adanya ketidak lancaran distribusi barang. Dengan kata lain, inflasi ini dapat terjadi karena permintaan masyarakat terhadap barangbarang lebih besar daripada jumlah yang tersedia di masyarakat sehingga terjadi kenaikan harga barang.

Sedangkan menurut Irham Fahmi(2011: 186), inflasi pada dasarnya dapat diartikan sebagai suatu kejadian yang menggambarkan situasi dan kondisi dimana harga barang mengalami kenaikan dan nilai mata uang mengalami pelemahan, dan jika ini terjadi secara terus menerus maka akan mengakibatkan pada memburuknya ekonomi secara menyeluruh serta mampu mengguncang tatanan stabilitas politik suatu Negara.

\subsection{Harga Minyak Dunia}

Minyak merupakan salah satu sumber energi yang dibutuhkan manusia dalam berbagai aspek kehidupan. Sejak tahun 2000 sudah terlihat bahwa harga minyak sedang mengalami pergolakan. Tiga tahun berikutnya harga terus naik seiring dengan menurunnya kapasitas cadangan.

Kenaikan harga minyak sendiri secara umum akan mendorong kenaikan harga saham sektor pertambangan. Hal ini disebabkan karena dengan peningkatan harga minyak akan memicu kenaikan harga bahan tambang secara umum. Ini tentu mengakibatkan perusahaan pertambangan berpotensi untuk meningkatkan labanya. Kenaikan harga saham pertambangan tentu akan mendorong kenaikan IHSG.

\subsection{Indeks Harga Saham Gabungan (IHSG)}

IHSG (Indeks Harga Saham Gabungan) merupakan indeks harga saham-saham yang digunakan oleh Bursa Efek Indonesia. IHSG merupakan barometer yang menunjukkan naik turunnya harga saham secara gabungan di BEI.

\subsection{Hipotesis}

$\mathrm{H}_{1}$ : Tingkat Suku Bunga BI berpengaruh secara signifikan terhadap Indeks Harga Saham Gabungan

$\mathrm{H}_{2}$ : Nilai tukar Rupiah terhadap USD berpengaruh secara signifikan terhadap Indeks Harga Saham Gabungan

$\mathrm{H}_{3}$ : Tingkat Inflasi berpengaruh secara signifikan terhadap Indeks Harga Saham Gabungan

$\mathrm{H}_{4}$ : Harga Minyak Dunia berpengaruh secara signifikan terhadap Indeks Harga Saham Gabungan 
$\mathrm{H}_{5}$ : $\quad$ Tingkat Suku Bunga BI, Nilai tukar Rupiah terhadap USD, Inflasi dan harga minyak dunia secara bersama-sama mempunyai pengaruh signifikan terhadap Indeks Harga Saham Gabungan

\section{METODOLOGI PENELITIAN}

\subsection{Jenis Penelitian}

Penelitian ini menggunakan jenis penelitian explanatory research dengan pendekatan kuantitatif. Penelitian ini bertujuan untuk menjelaskan pengaruh makro ekonomi terhadap Indeks Harga Saham Gabungan (IHSG)

\subsection{Sumber Data Penelitian}

Penelitian ini menggunakan data sekunder berupa time series yang diakses pada situs resmi Bank Indonesia dan Yahoo Finance

\subsection{Variabel dan Pengukuran}

Penelitian ini menggunakan empat variable bebas $(\mathrm{X})$ dan satu variable terikat $(\mathrm{Y})$. Variabel penelitian dalam jurnal ini adalah sebagai berikut:

Tabel 1 : Variabel dan pengukuran

\begin{tabular}{|l|l|l|l|}
\hline NO & VARIABEL & SIMBOL & SATUAN \\
\hline 1 & IHSG & IHSG/Y & IDR \\
\hline 2 & Suku Bunga & INT/X1 & Persen(\%) \\
\hline 3 & Nilai Tukar & KURS/X2 & IDR \\
\hline 4 & Inflasi & INF/X3 & Persen(\%) \\
\hline 5 & Harga Minyak Dunia & PRICE & USD/ Barrel \\
\hline
\end{tabular}

Sumber : Data diolah

\subsection{Populasi Dan Sampel}

Populasi dalam penelitian ini adalah data-data time series yang tersedia pada website resmi Bank Indonesia dan Yahoo Finance periode tahun 2013 hingga tahun 2017 yang diolah ke dalam data bulanan. Penentuan sampel dalam penelitian ini menggunakan teknik sampling jenuh, yaitu teknik penggunaan sampel dimana semua anggota populasi digunakan sebagai sampel.

\subsection{Teknik Analisis Data}

Penelitian ini bertujuan untuk menganalisis pengaruh makroekonomi (yang meliputi tingkat suku bunga, kurs, inflasi, dan harga minyak dunia) terhadap Indeks Harga Saham Gabungan atau IHSG dengan menggunakan analisis regresi linier berganda. Persamaan Model regresi berganda adalah sebagai berikut :

$\mathrm{Y}=\mathrm{a}+\mathrm{b}_{1} \mathrm{X} 1+\mathrm{b}_{2} \mathrm{X} 2+\mathrm{b}_{3} \mathrm{X} 3+\mathrm{b}_{4} \mathrm{X} 4+\mathrm{e}$

Keterangan

Y : Variabel Dependen (Variabel Terikat)

a : Konstanta

$\mathrm{b}_{1}-\mathrm{b}_{4} \quad$ : Koefisien Regresi

$\mathrm{X}_{1}-\mathrm{X}_{4}$ : Variabel Independen (Variabel Bebas)

e : Kesalahan Pengganggu

\subsection{Pengujian Asumsi Klasik}

Analisis regresi dapat dilakukan hanya setelah memenuhi beberapa asumsi-asumsi klasik seperti uji multikolinieritas, autokorelasi, heteroskedastisitas dan normalitas. Pengujian ini dilakukan dengan alasan supaya data yang diperoleh tidak bias. Uji asumsi klasik dalam penelitian ini terdiri dari uji normalitas, uji multikolinieritas, uji heteroskedastisitas dan uji autokorelasi.

\subsection{Pengujian Hipotesis}




\section{a. Uji Koefisien Determinasi $\left(\mathbf{R}^{2}\right)$}

Analisis determinasi $\mathrm{R}^{2}$ digunakan untuk mengetahui proporsi sumbangan variabel independen terhadap variabel dependen. $\mathrm{R}^{2}$ memberikan suatu ukuran secara keseluruhan mengenai sejauh mana variasi dalam sebuah variabel menentukan variasi dalam variable lain. $\mathrm{R}^{2}$ bernilai antara nol sampai dengan satu.

\section{b. Uji Simultan (F)}

Uji F digunakan untuk mengetahui apakah semua variabel independen yang digunakan dalam penelitian mempunyai pengaruh secara serentak terhadap variabel dependen. Pengujian dilakukan dengan cara uji distribusi $\mathrm{F}$ dengan membandingkan nilai F-tabel dengan F-hitung yang terdapat pada tabel Analysis Variance.

\section{c. Uji Parsial (Uji t)}

Uji $\mathrm{t}$ dilakukan untuk memastikan seberapa besar pengaruh variabel independen terhadap variabel dependen secara terpisah. Uji t juga dilakukan untuk menguji signifikansi nilai koefisien regresi secara parsial yang diperoleh dalam metode OLS. Hipotesis yang digunakan dalam penelitian ini menggunakan taraf nyata sebesar $5 \%$.

\section{ANALISIS DAN BAHASAN TEMUAN}

\subsection{Statistik Deskriptif}

Tabel 4.1 Hasil Analisis Statistik Deskriptif Variabel Penelitian

\begin{tabular}{|c|c|c|c|c|c|}
\hline & $\mathrm{N}$ & $\begin{array}{l}\text { Minimu } \\
\mathrm{m}\end{array}$ & $\begin{array}{l}\text { Maximu } \\
\mathrm{m}\end{array}$ & Mean & $\begin{array}{l}\text { Std. } \\
\text { Deviation }\end{array}$ \\
\hline IHSG & 60 & 4195.089 & 6355.654 & $\begin{array}{l}5052.7839 \\
8\end{array}$ & 503.842405 \\
\hline INT & 60 & 4.25 & 7.75 & 6.4083 & 1.23848 \\
\hline KURS & 60 & 9678.00 & 14654.00 & $\begin{array}{l}12469.083 \\
3\end{array}$ & 1312.11056 \\
\hline INF & 60 & 2.79 & 8.79 & 5.4215 & 1.84443 \\
\hline PRICE & 60 & 29.78 & 108.76 & 69.3367 & 26.96163 \\
\hline $\begin{array}{ll}\text { Valid } & \mathrm{N} \\
\text { (listwise) } & \end{array}$ & 60 & & & & \\
\hline
\end{tabular}

Variabel IHSG memiliki nilai minimum sebesar 4195.089 yang merupakan harga saham penutupan pada bulan Agustus 2013 dan memiliki nilai maksimum 6355.654 yang merupakan harga saham penutupan pada bulan Desember 2017. Nilai rata-rata IHSG sebesar 5052.784 yang merupakan rata-rata harga saham saat penutupan pada periode Januari 2013 Desember 2017 dan nilai standar deviasi sebesar 503.842 yang merupakan variasi data dari harga saham saat penutupan pada periode Januari 2013 - Desember 2017.

Variabel suku Bunga BI memiliki nilai minimum sebesar 4.25 yang merupakan tingkat suku bunga BI pada bulan September 2017 - Desember 2017 dan memiliki nilai maksimum sebesar 7.75 yang merupakan tingkat suku bunga BI pada bulan November 2014 - Januari 2015. Nilai rata-rata suku bunga BI sebesar 6.4083 yang merupakan rata-rata suku bunga BI yang terjadi pada periode Januari 2013 - Desember 2017 dan nilai standar deviasi sebesar 1.23848 yang merupakan variasi data dari suku bunga BI pada periode Januari 2013 Desember 2017.

Variabel nilai tukar kurs Rupiah terhadap USD memiliki nilai minimum sebesar 9678 yang merupakan nilai kurs tengah minimum pada bulan Maret 2013 dan memiliki nilai maksimum sebesar 14654 yang merupakan nilai kurs tengah maksimum pada bulan Oktober 
2015. Nilai rata-rata kurs sebesar 12469.0833 yang merupakan rata-rata nilai kurs yang terjadi pada periode Januari 2013 - Desember 2017 dan nilai standar deviasi sebesar 1312.11056 yang merupakan variasi data dari nilai tukar kurs pada periode Januari 2013 Desember 2017.

Variabel inflasi memiliki nilai minimum sebesar 2.79 yang merupakan inflasi pada bulan Agustus 2016 dan memiliki nilai maksimum sebesar 8.79 yang merupakan inflasi pada bulan Agustus 2013. Nilai rata-rata inflasi sebesar 5.4215 yang merupakan rata-rata inflasi yang terjadi pada periode Januari 2013 - Desember 2017 dan nilai standar deviasi sebesar 1.84443 yang merupakan variasi data dari inflasi pada periode Januari 2013 - Desember 2017.

Variabel harga minyak dunia memiliki nilai minimum 29.78 yang merupakan harga minyak dunia pada bulan Januari 2016 dan memiliki nilai maksimum sebesar 108.76 yang merupakan harga minyak dunia pada bulan September 2013. Nilai rata-rata harga minyak dunia sebesar 69.3367 yang merupakan rata-rata harga minyak dunia yang terjadi pada periode Januari 2013 - Desember 2017 dan nilai standar deviasi sebesar 26.96163.

4.2. Uji Asumsi Klasik

4.2.1 Uji Normalitas

Tabel 4.2 Hasil Analisis Normalitas dengan Uji Statistik

One-Sample Kolmogorov-Smirnov Test

\begin{tabular}{|c|c|c|}
\hline & & $\begin{array}{l}\text { Unstandardiz } \\
\text { ed Residual }\end{array}$ \\
\hline \multirow[t]{2}{*}{$\mathrm{N}$} & & 84 \\
\hline & Mean & $0 \mathrm{E}-7$ \\
\hline Normal Parameters ${ }^{\mathrm{a}, \mathrm{b}}$ & Std. & .07287335 \\
\hline \multirow{3}{*}{$\begin{array}{l}\text { Most } \\
\text { Differences }\end{array}$} & Absolute & .060 \\
\hline & Positive & .060 \\
\hline & Negative & -.037 \\
\hline \multicolumn{2}{|c|}{ Kolmogorov-Smirnov Z } & .548 \\
\hline \multicolumn{2}{|l|}{ Asymp. Sig. (2-tailed) } & .925 \\
\hline
\end{tabular}

a. Test distribution is Normal.

b. Calculated from data.

Sumber : Hasil Pengolahan SPSS 20 for Windows 


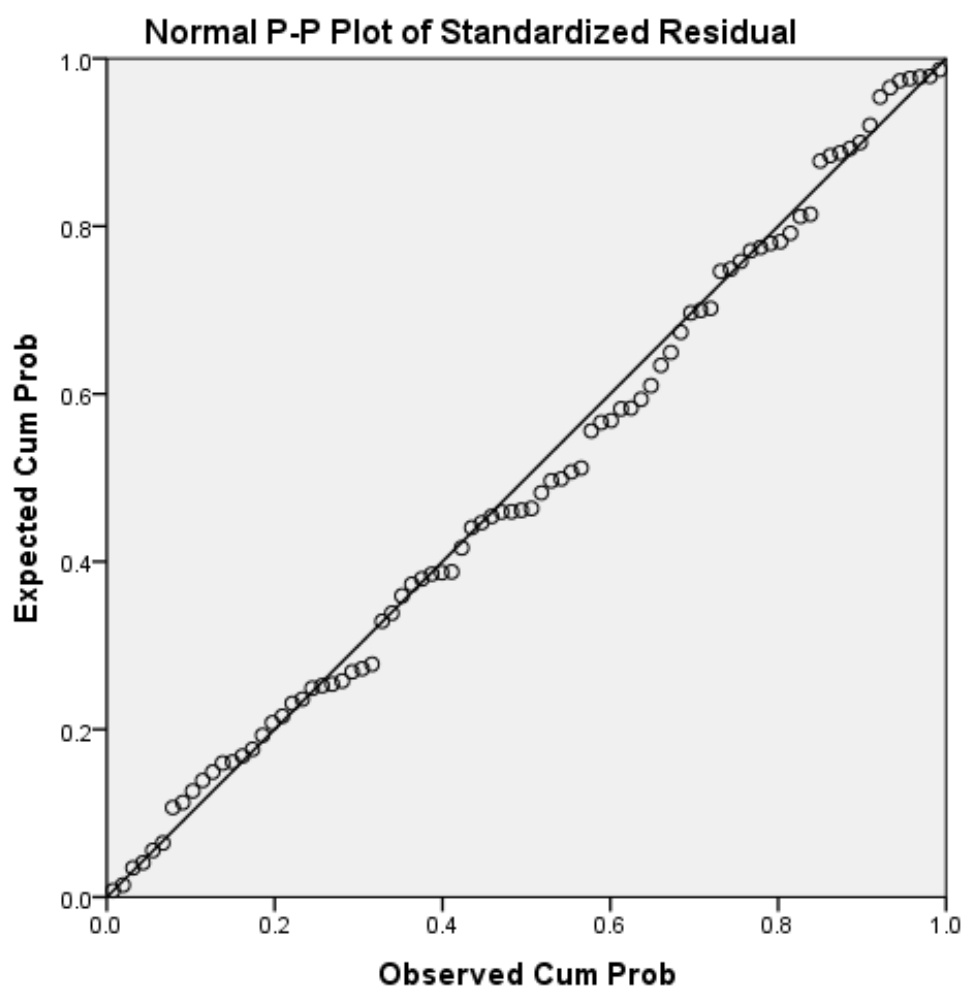

Gambar 4.1 Hasil Uji Normalitas dengan Normal Probability Plot

Sumber : Hasil Pengolahan SPSS 20 for Windows

Berdasarkan hasil pengujian normalitas data di atas diketahui bahwa nilai Asymp.Sig (2-tailed) memiliki signifikansi > 0,05 maka dapat disimpulkan bahwa variabel bebas dan variabel terikat sudah terdistribusi secara normal.

Pada grafik Normal Probability Plot terlihat bahwa data yang dinyatakan dalam bentuk titik menyebar di sekitar garis diagonal dan mengikuti arah garis diagonal. Berdasarkan analisis tersebut dapat diambil kesimpulan bahwa model regresi berganda dalam penelitian ini baik dan layak digunakan untuk memprediksi pengaruh dari suku bunga BI, nilai tukar, inflasi, dan harga minyak dunia terhadap IHSG periode Januari 2013 - Desember 2017 karena telah memenuhi asumsi normalitas.

4.2.2 Uji Multikolinearitas

Tabel 4.3 Hasil Uji Multikolinearitas

\begin{tabular}{|c|c|c|c|c|c|c|c|c|}
\hline \multirow{2}{*}{\multicolumn{2}{|c|}{ Model }} & \multicolumn{2}{|c|}{$\begin{array}{l}\text { Unstandardized } \\
\text { Coefficients }\end{array}$} & \multirow{2}{*}{\begin{tabular}{|l} 
Standardized \\
Coefficients \\
Beta
\end{tabular}} & \multirow[t]{2}{*}{$\mathrm{t}$} & \multirow[t]{2}{*}{ Sig. } & \multicolumn{2}{|c|}{$\begin{array}{l}\text { Collinearity } \\
\text { Statistics }\end{array}$} \\
\hline & & B & Std. Error & & & & Tolerance & VIF \\
\hline \multirow{5}{*}{1} & (Constant) & -.011 & .147 & & -.076 & .940 & & \\
\hline & Ln_INT & .012 & .009 & .188 & 1.335 & .186 & .547 & 1.828 \\
\hline & Ln_KURS & .002 & .013 & .028 & .141 & .888 & .270 & 3.706 \\
\hline & Ln_INF & .008 & .006 & .221 & 1.405 & .164 & .441 & 2.269 \\
\hline & Ln_PRICE & -.006 & .006 & -.204 & -.945 & .348 & .234 & 4.281 \\
\hline
\end{tabular}

Sumber : Hasil Pengolahan SPSS 20 for Windows

Pada Tabel 4.3 terlihat nilai VIF (Variance Inflation Factor) dari setiap variabel independen pada penelitian ini. Variabel suku bunga BI memiliki nilai VIF sebesar 1.828 dengan Tolerance sebesar 0.547 , variabel nilai tukar kurs memiliki nilai VIF sebesar 3.706 
dengan Tolerance sebesar 0.270, variabel inflasi memiliki nilai VIF sebesar 2.269 dengan Tolerance sebesar 0.441, dan variabel harga minyak dunia memiliki nilai VIF sebesar 4.281 dengan Tolerance sebesar 0.234 .

Berdasarkan nilai-nilai tersebut, dapat dilihat bahwa nilai VIF (Variance Inflation Factor) seluruh variabel bebas lebih kecil dari 10 dan nilai Tolerance lebih besar dari 0,1, maka dapat disimpulkan bahwa dalam model regresi yang digunakan dalam penelitian ini tidak terdapat masalah multikolinearitas. Hal ini menunjukkan bahwa antar variabel bebas yaitu suku bunga BI, nilai tukar, inflasi, dan harga minyak dunia tidak memiliki hubungan linear satu dengan yang lainnya sehingga layak digunakan untuk analisis.

4.2.3 Uji Heteroskedastisitas

Tabel 4.4 Hasil Uji Heteroskedastisitas dengan Uji Gletzer

\begin{tabular}{|c|c|c|c|c|c|c|c|c|}
\hline \multirow{2}{*}{\multicolumn{2}{|c|}{ Model }} & \multicolumn{2}{|c|}{$\begin{array}{l}\text { Unstandardized } \\
\text { Coefficients }\end{array}$} & $\begin{array}{l}\text { Standardized } \\
\text { Coefficients }\end{array}$ & \multirow[t]{2}{*}{$\mathrm{t}$} & \multirow[t]{2}{*}{ Sig. } & \multicolumn{2}{|c|}{$\begin{array}{l}\text { Collinearity } \\
\text { Statistics }\end{array}$} \\
\hline & & B & Std. Error & Beta & & & Tolerance & VIF \\
\hline \multirow{5}{*}{1} & (Constant) & -.011 & .147 & & -.076 & .940 & & \\
\hline & Ln_INT & .012 & .009 & .188 & 1.335 & .186 & .547 & 1.828 \\
\hline & Ln_KURS & .002 & .013 & .028 & .141 & .888 & .270 & 3.706 \\
\hline & Ln_INF & .008 & .006 & .221 & 1.405 & .164 & .441 & 2.269 \\
\hline & Ln_PRICE & -.006 & .006 & -.204 & -.945 & .348 & .234 & 4.281 \\
\hline
\end{tabular}

Sumber : Hasil Pengolahan SPSS 20 for Windows

Pada Tabel 4.4 dapat dilihat bahwa semua variabel independen memiliki nilai signifikan di atas 0.05 , sehingga menunjukkan bahwa data tidak memiiki masalah heteroskedastisitas.

4.3 Pengujian Hipotesis

Tabel 4.6 Tabel Coefficient dengan Variabel Dependen Harga Saham (IHSG)

\section{Coefficients $^{\mathrm{a}}$}

\begin{tabular}{|c|c|c|c|c|c|c|}
\hline \multirow{2}{*}{\multicolumn{2}{|c|}{ Model }} & \multicolumn{2}{|c|}{$\begin{array}{l}\text { Unstandardized } \\
\text { Coefficients }\end{array}$} & $\begin{array}{l}\text { Standardized } \\
\text { Coefficients }\end{array}$ & \multirow[t]{2}{*}{$\mathrm{t}$} & \multirow[t]{2}{*}{ Sig. } \\
\hline & & B & Std. Error & Beta & & \\
\hline \multirow{5}{*}{1} & (Constant & 6.202 & 1.476 & & 4.202 & .000 \\
\hline & Ln_INT & -.282 & .059 & -.595 & -4.801 & .000 \\
\hline & Ln_KUR & .289 & .142 & .326 & 2.038 & .046 \\
\hline & Ln_INF & -.043 & .042 & -.149 & -1.017 & .314 \\
\hline & $\begin{array}{l}\text { Ln_PRIC } \\
\text { E }\end{array}$ & .045 & .045 & .177 & 1.005 & .319 \\
\hline
\end{tabular}


Sumber : Hasil Pengolahan SPSS 20.0 for Windows

Tabel 4.6 menunjukkan koefisien regresi dari model regresi yang digunakan dalam penelitian. Koefisien regresi menunjukkan arah perubahan variabel independen terhadap variabel dependen. Berdasarkan nilai $\alpha$ Constant, $\beta$ (INT), $\beta$ (KURS), $\beta$ (INF), dan $\beta$ (PRICE), maka model regresi linear berganda yang terbentuk adalah :

IHSG $=6,202-0,282 I N T+0.289 K U R S-0,043 I N F+0,045 P R I C E$

Dapat dilihat pada model regresi diatas, Koefisien terbesar adalah koefisien Kurs yaitu 0,289 dan koefisien terkecil adalah koefisien Inflasi yaitu -0,043.

$\alpha=6,202$ menunjukkan apabila suku bunga BI, kurs, inflasi, dan harga minyak dunia masingmasing bernilai nol atau diabaikan, maka harga saham akan bernilai 6,202 satuan.

$\beta_{1}=-0,282$ menunjukkan bahwa kenaikan satu satuan suku bunga BI, maka akan mengakibatkan berkurangnya harga saham sebesar 0,282 dengan asumsi bahwa kurs, inflasi, dan harga minyak dunia konstan.

$\beta_{2}=0,289$ menunjukkan bahwa kenaikan satu satuan kurs, maka akan mengakibatkan meningkatnya harga saham sebesar 0,289 satuan dengan asumsi bahwa suku bunga BI, inflasi, dan harga minyak dunia konstan.

$\beta_{3}=-0,043$ menunjukkan bahwa kenaikan satu satuan inflasi, maka akan mengakibatkan berkurangnya harga saham sebesar 0,043 satuan dengan asumsi bahwa suku bunga BI, nilai tukar kurs, dan harga minyak dunia konstan.

$\beta_{4}=0,045$ menunjukkan bahwa kenaikan satu satuan harga minyak dunia, maka akan mengakibatkan meningkatnya harga saham sebesar 0,045 satuan dengan asumsi bahwa suku bunga BI, nilai tukar kurs, dan inflasi konstan.

\subsubsection{Uji t}

Tabel 4.7 Hasil Uji t-test

\section{Coefficients $^{\mathrm{a}}$}

\begin{tabular}{|c|c|c|c|c|c|c|}
\hline \multirow{2}{*}{\multicolumn{2}{|c|}{ Model }} & \multicolumn{2}{|c|}{$\begin{array}{l}\text { Unstandardized } \\
\text { Coefficients }\end{array}$} & \multirow{2}{*}{$\begin{array}{l}\text { Standardized } \\
\text { Coefficients } \\
\text { Beta }\end{array}$} & \multirow[t]{2}{*}{$\mathrm{t}$} & \multirow[t]{2}{*}{ Sig. } \\
\hline & & $\mathrm{B}$ & Std. Error & & & \\
\hline \multirow{5}{*}{1} & (Constant & 6.202 & 1.476 & & 4.202 & .000 \\
\hline & Ln_INT & -.282 & .059 & -.595 & -4.801 & .000 \\
\hline & $\begin{array}{l}\text { Ln_KUR } \\
\text { S }\end{array}$ & .289 & .142 & .326 & 2.038 & .046 \\
\hline & Ln_INF & -.043 & .042 & -.149 & -1.017 & .314 \\
\hline & $\begin{array}{l}\text { Ln_PRIC } \\
\text { E }\end{array}$ & .045 & .045 & .177 & 1.005 & .319 \\
\hline
\end{tabular}

Sumber : Hasil Pengolahan SPSS 20.0 for Windows

Pada Tabel 4.7 terlihat bahwa variabel independen suku bunga BI memiliki nilai signifikansi 0,000 sehingga lebih kecil dari 0,05. Dengan demikian menunjukkan bahwa Ho diterima, yaitu tingkat suku bunga BI berpengaruh signifikan terhadap harga saham.

Pada Tabel 4.7 terlihat bahwa variabel independen nilai tukar kurs memiliki nilai signifikansi 0,046 sehingga lebih kecil dari 0,05. Dengan demikian menunjukkan bahwa Ho diterima, yaitu nilai tukar kurs berpengaruh signifikan terhadap harga saham. 
Pada Tabel 4.7 terlihat bahwa variabel independen inflasi memiliki nilai signifikansi 0,314 sehingga lebih besar dari 0,05. Dengan demikian menunjukkan bahwa Ho ditolak, yaitu tingkat inflasi tidak berpengaruh signifikan terhadap harga saham.

Pada Tabel 4.7 terlihat bahwa variabel independen harga minyak dunia memiliki nilai signifikansi 0,319 sehingga lebih besar dari 0,05. Dengan demikian menunjukkan bahwa Ho ditolak, yaitu harga minyak dunia tidak berpengaruh signifikan terhadap harga saham.

4.3.2 Uji F

Tabel 4.8 Hasil uji F-test

ANOVA ${ }^{\mathrm{a}}$

\begin{tabular}{|ll|l|l|l|l|l|}
\hline \multicolumn{2}{|l|}{ Model } & $\begin{array}{l}\text { Sum of } \\
\text { Squares }\end{array}$ & df & $\begin{array}{l}\text { Mean } \\
\text { Square }\end{array}$ & F & Sig. \\
\hline \multirow{3}{*}{1} & Regression & .321 & 4 & .080 & 17.223 & $.000^{\mathrm{b}}$ \\
& Residual & .256 & 55 & .005 & & \\
& Total & .577 & 59 & & & \\
\hline
\end{tabular}

Sumber : Hasil Pengolahan SPSS 20.0 for Windows

Berdasarkan data pada Tabel 4.8 dari pengujian secara bersama-sama (simultan), diperoleh nilai signifikan sebesar 0,000 yaitu lebih kecil dari nilai $\alpha=0,05$. Dengan demikian dapat disimpulkan bahwa terdapat pengaruh yang signifikan antara variabel independen (suku bunga BI, kurs, inflasi, dan harga minyak dunia) terhadap variabel dependen (harga saham) dengan tingkat keyakinan $95 \%$.

4.4 Uji Koefisien Determinasi (Adj $R$ square)

Tabel 4.10 Hasil Uji Koefisien Determinasi

Model Summary ${ }^{b}$

\begin{tabular}{|l|l|l|l|l|l|}
\hline $\begin{array}{l}\text { Mode } \\
1\end{array}$ & $\mathrm{R}$ & R Square & $\begin{array}{l}\text { Adjusted R } \\
\text { Square }\end{array}$ & $\begin{array}{l}\text { Std. Error of } \\
\text { the Estimate }\end{array}$ & $\begin{array}{l}\text { Durbin- } \\
\text { Watson }\end{array}$ \\
\hline 1 & $.864^{\mathrm{a}}$ & .746 & .733 & .075 & .324 \\
\hline
\end{tabular}

Sumber : Hasil Pengolahan SPSS 20.0 for Windows

Pada Tabel 4.10 diperoleh nilai Adjusted $R$ Square adalah 0,733. Hal ini menunjukkan bahwa 73,3\% variabel dependen yaitu harga saham dapat dijelaskan oleh variabel independen (suku bunga BI, nilai tukar kurs, inflasi, dan harga minyak dunia). Sedangkan sisanya, yaitu sebesar 26,7\% (100\%-73,3\%) dijelaskan oleh faktor lain di luar model regresi pada penelitian ini.

\section{Kesimpulan dan Saran}

\subsection{Kesimpulan}

Berdasarkan hasil analisis dan pembahasan, maka kesimpulan yang didapat pada penelitian ini, yaitu :

1. Suku bunga BI dan nilai tukar kurs secara parsial mempengaruhi IHSG. Sedangkan inflasi dan harga minyak dunia secara parsial tidak mempengaruhi IHSG.

2. Berdasarkan uji-F yang dilakukan, diperoleh hasil bahwa suku bunga BI, nilai tukar kurs, inflasi, dan harga minyak dunia secara simultan memiliki pengaruh signifikan terhadap indeks harga saham gabungan di bursa efek Indonesia (BEI) periode tahun 2013-2017. Hal ini terlihat pada nilai signifikansi sebesar $0.000(\alpha<=0,05)$.

3. $73,3 \%$ IHSG dapat dipengaruhi oleh suku bunga BI, nilai tukar kurs, inflasi dan harga minyak dunia.

\subsection{Saran}


Setelah melakukan analisis pada penelitian ini, beberapa saran yang dapat diberikan sebagai masukan untuk peneitian berikutnya yaitu :

1. Penelitian ini dilakukan pada periode Januari 2013 - Desember 2017 di mana pada tahun 2016 terjadi perubahan Suku bunga BI menjadi BI 7-Day Repo Rate yang mulai berlaku sejak Agustus 2016. Selain itu, rentang tahun yang lebih panjang akan membuat investor memiliki gambaran yang lebih luas akan perubahan harga saham yang mungkin terjadi.

2. Penelitian ini hanya menggunakan variabel independen suku bunga BI, nilai tukar kurs, inflasi, dan harga minyak dunia sebagai indikator penyebab perubahan indeks harga saham di BEI. Hal ini terlihat pada nilai Adjusted $\mathrm{R}$ square yang hanya sebesar 0,733 pada uji koefisien determinasi. Jadi disarankan agar melakukan penambahan jumlah variabel selain keempat faktor independen tersebut.

3. Penelitian ini hanya menggunakan empat variabel makro ekonomi dan tidak memperhatikan faktor kondisi sosial, politik, dan keamanan yang terjadi di Indonesia yang juga dapat mempengaruhi kinerja pasar saham.

4. Model penelitian yang digunakan pada penelitian ini adalah model analisis regresi linear berganda. Untuk penelitian berikutnya disarankan untuk dapat menggunakan model analisis regresi stepwise untuk dapat mengetahui model terbaik dari sebuah analisis regresi dengan beberapa variabel independen. Dengan model analisis regresi stepwise akan diketahui variabel mana yang paling berpengaruh secara signifikan pada model persamaan regresi yang digunakan. Variabel yang tidak berpengaruh signifikan akan dikeluarkan dari model .

\section{REFERENSI}

Auliyah, Robiatul dan Ardi Hamzah. 2006. Analisa Karakteristik Perusahaan, Industri Dan Ekonomi Makro Terhadap Return Dan Beta Saham Syariah Di Bursa Efek Jakarta. Simposium Nasional Akuntansi 9 Padang.

Budialim, Giovanni. 2013. Pengaruh Kinerja Keuangan dan Risiko Terhadap Return Saham Sektor Consumer Goods di Bursa Efek Indonesia periode 2007-2011. Jurnal Ilmiah Mahasiswa Universitas Surabaya. Vol. 2 No. 1

Fahmi, Irham. 2012. Pengantar Pasar Modal. Bandung : Alfabeta.

Fakhruddin, M., dan M. Sopian Hadinanto, 2001. Perangkat dan Model Analisis Investasi di Padar Modal. Buku Kesatu, PT. Alex Media Komputindo, Jakarta.

Hariyanto, M.Y Dedi dan Riyatno. 2007. Pengaruh Suku Bunga Sertifikat Bank Indonesia dan Nilai Kurs Terhadap Risiko Sistematik Saham Perusahaan di BEJ. Jurnal Keuangan dan Bisnis. Vol. 5, No. 1, Hal 24-40.

Hartono, Jogiyanto. 2013. Teori Portofolio \& Analisis Investasi. Edisi ketujuh. Yogyakarta : BPFE. Husnan, Suad. 2009. Teori Portofolio \& Analisis Sekuritas. Edisi keempat. Yogyakarta : UPP STIM YKPN

Khoirul, Anwar. 2010. Pengaruh Tingkat Inflasi, Suku Bunga SBI, Kurrs, dan IHSG Terhadap Kinerja Reksadana Saham. Surabaya

Nopirin. 2012. Pengantar Ilmu Ekonomi Makro \& Mikro, First Edition. Yogyakarta: BPFE.

Putra, Dianata Eka, 2003 Berburu Uang di Pasar Modal. Cetakan Kedua, Effhar dan Dahara Prize, Semarang.

Santoso, Singgih, 2000. SPSS Mengolah Data Statistik Secara Profesional. PT. Elex Media Komputindo, Kelompok Gramedia, Jakarta.

Tandelilin, Eduardus. 2010. Analisis Investasi dan Manajemen Portofolio. Edisi 1. Yogyakarta : BPFE Taujik. Kajian Capital Market Dan Leverage Tehadap Variasi Harga Saham Di Bursa Efek Jakarta. Keuangan.

Trevino, Ruben dan Fiona Robertson, 2002. P/E Rations and Stock Market Return. Journal of Financial Planning. 
Waluyo, Minto. 2009. Panduan dan Aplikasi Structural Equation Modelling. Cetakan 1. Jakarta : PT Indeks

http://www.bi.go.id/

http://www.idx.co.id/

http://finance.yahoo.com/ 
